Pediat. Res. 10: 566-570 (1976)

Bohr effect

congenital heart disease

2,3-diphosphoglycerate newborns

$\mathrm{P}_{50}$

shunt hypoxemia

\title{
Oxygen Transport in Congenital Heart Disease: Influence of Fetal Hemoglobin, Red Cell pH, and 2,3-Diphosphoglycerate
}

\author{
H. T. VERSMOLD, ${ }^{37}$ C. LINDERKAMP, C. DÖHLEMANN, AND K. P. RIEGEL \\ Division of Neonatology, Kinderklinik der Universität, Munich, Federal Republic of Germany
}

\section{Extract}

In 48 individuals (age 1 day to 13 years) with congenital heart disease, blood oxygen transport function was studied in order to evaluate adaptive changes in shunt hypoxemia and to investigate the in vivo regulation of erythrocyte 2,3 -diphosphoglycerate concentration (RBC 2,3-DPG) in the presence of fetal hemoglobin ( $\mathrm{HbF}$ ). Arterial $\mathrm{pO}_{2}$ and oxygen content, oxygen capacity, acid base status, oxygen affinity, $\mathrm{HbF}$ fraction, plasma $\mathrm{pH}$, red cell $\mathrm{pH}$, and $\mathrm{RBC}$ 2,3-DPG were determined. During the first 50 days of life values of standard $\mathbf{P}_{50}\left(\operatorname{stdP}_{50}\right)\left(37^{\circ}, \mathbf{p H} 7.4\right)$, actual in vivo $\mathbf{P}_{50}\left(\operatorname{act} \mathbf{P}_{50}\right)$, $\mathrm{RBC}$ 2,3-DPG, $\mathrm{O}_{2}$ capacity, arterial plasma $\mathrm{pH}$, and red cell $\mathrm{pH}$ were scattered around the normal range, although tending to low values for $\mathbf{s t d P}_{50}$ and arterial plasma $\mathrm{pH}$ and to high values for $\mathrm{O}_{2}$ capacity. After the third month, stdP $\mathrm{P}_{50}$ act $_{50}, \mathrm{RBC} 2,3-\mathrm{DPG}, \mathrm{O}_{2}$ capacity, and red cell $\mathrm{pH}$ were found to be elevated. Plasma $\mathrm{pH}$ and act $P_{50}$ were scattered around the normal range (Figs. 1 and 2 ).

Intraerythrocytic $\mathrm{pH}$ in hypoxemic infants was increased compared with normal children when related to plasma pH (Fig. 3). A close to normal intraerythrocytic $\mathrm{pH}$ was therefore found in the hypoxemic infants with low plasma $\mathrm{pH}$, and an increased intraerythrocytic $\mathrm{pH}$ in the hypoxemic children with normal plasma $\mathrm{pH}$ ( Fig. 1). A significant negative correlation exists between erythrocyte $\mathbf{H}^{+}$ ion and 2,3-DPG concentration (Fig. 5); regression constants derived from data at high (mean $47 \%$ ) and low (mean $9 \%$ ) fractions of $\mathrm{HbF}$ are not significantly different (Regression Equations 8 and 11 in Table 1). Thus, the known difference in 2,3-DPG binding to fetal or adult deoxyhemoglobin does not measurably influence the erythrocyte 2,3-DPG concentration, indicating that in vivo the 2,3DPG synthesis in hypoxia is virtually regulated by the erythrocyte $\mathrm{pH}$, which in turn is determined by plasma $\mathrm{pH}$ and the oxygenation state of hemoglobin.

\section{Speculation}

In young infants and older children with cyanotic heart disease an identical negative correlation between the concentrations of 2,3DPG and hydrogen ions within the erythrocyte was found. The in vivo regulation of 2,3-DPG synthesis thus appears to be controlled by the erythrocyte $\mathrm{pH}$ which, in turn, is determined by plasma $\mathrm{pH}$ and oxygen saturation of hemoglobin. Apparently the well established difference of 2,3-DPG binding to fetal or adult deoxyhemoglobin does not measurably influence the erythrocyte 2,3-DPG concentration, indicating that in vivo a relief of product inhibition of the diphosphoglycerate mutase does not contribute significantly to the regulation of 2,3-DPG synthesis in hypoxemia.

Chronic hypoxemia in congenital heart disease is associated with low affinity of blood for oxygen (high $P_{50}$ value), both in adults ( 19 , $24)$ and in children older than 4 months $(19,24)$, because of an increased erythrocyte $2,3-\mathrm{DPG}$ concentration $(20,24,31)$. It has been suggested that low hemoglobin $\mathrm{O}_{2}$ affinity improves oxygen delivery to tissues, as has been experimentally confirmed for anemic hypoxia on isolated perfused livers (27).

In the human newborn blood oxygen affinity depends mainly on the relation of fetal to adult hemoglobin $(\mathrm{HbA})$ and on red cell $\mathrm{pH}$. $\mathrm{HbF}$ reacts to a lesser extent with $\mathrm{RBC} 2,3-\mathrm{DPG}$. In this age group lowered blood oxygen affinity and elevated 2,3-DPG have been described (12) in cyanotic infants with congenital cardiac malformations. Detailed information on parameters of blood oxygen transport in infants during the first months of life is lacking in regard to congenital heart disease.

The mechanism of the in vivo regulation of 2,3-DPG synthesis during hypoxia is still under discussion (2, 13, 14, 21, 23). Prevailing influences of $\mathrm{pH}$ or of 2,3-DPG binding to deoxyhemoglobin (13) are alleged. Since 2,3-DPG is less bound to deox y- $\mathrm{HbH}$ than to deoxy- $\mathrm{Hb} \wedge(11)$, a comparison of findings in young infants and older children with cyanotic heart disease should give useful information regarding those factors which control the erythrocyte 2,3-DPG concentration and, thus, the red cell adaptation to hypoxemia.

\section{METHODS}

PATILNTS

Fifty-three children with congenital heart disease were examined, 39 of whom were cyanotic (transposition of the great vessels. $n=23$ ). Seven infants were studied on two, and one infant on five occasions. Sixteen examinations were performed at an age $<30$ days, $35<4$ months, $47<1$ year. The acyanotic children did not suffer from severe cardiac failure. Data are compared with those for normal infants (29) who were studied simultaneously by the same methods. At the time of study all individuals had normal body temperature.

\section{PROCEDURES}

In all individuals blood was withdrawn at routine measures for diagnosis (e.g., during cardiac catheterization) or for clinical control with informed consent of parents. At each observation a total of approximately $3 \mathrm{ml}$ arterial and venous blood were collected in heparinized glass syringes. Specimens were processed within $2 \mathrm{hr}$ and kept at $4^{\circ}$ until analysis. The methods used have been described in detail elsewhere (29). Oxygen content was measured by means of gas chromatography (Beckman GCM), oxygen tension with a Clark-type oxygen electrode (Instrumentation Laboratories $\mathrm{pH} /$ gas analyzer, model 113), $\mathrm{pH}$ with a microglass-electrode (Instrumentation Laboratories). Red cell pH was measured directly (16) using a freeze-thaw technique. Fetal hemoglobin was measured by alkali denaturation (7), and RBC 2,3-DPG enzymatically by a kinetic test (8). Whole blood $\operatorname{std} \mathbf{P}_{50}$ was determined graphically using a Bohr factor $\left(\Delta \log \mathrm{pO}_{2} / \Delta \mathrm{pH}\right)$ $=-0.50(29)$; act $P_{s 0}$ was derived from the actual in vivo data. 
Linear regression lines were compared with regard to the probability of nonidentity of the slope (b) and the intercept (a) (15).

\section{RESULTS}

\section{INFANTS WITH ACYANOTIC HEART DISEASF}

The parameters studied (Figs. I and 2) did not differ from the values for healthy children in their age-dependent course. These findings are in agreement with those reported for adults with acyanotic heart disease and minor cardiac failure $(18,32)$.

\section{INFANTS WITH CYANOTIC HEART DISEASE}

Arterial oxygen tension ( $\mathrm{paO}_{2}$ ) of this group ranged from 14.4 to 61.4 Torr. Arterial $\mathrm{pCO}_{2}$ was found to be low or normal; two infants had moderate hypercapnia.

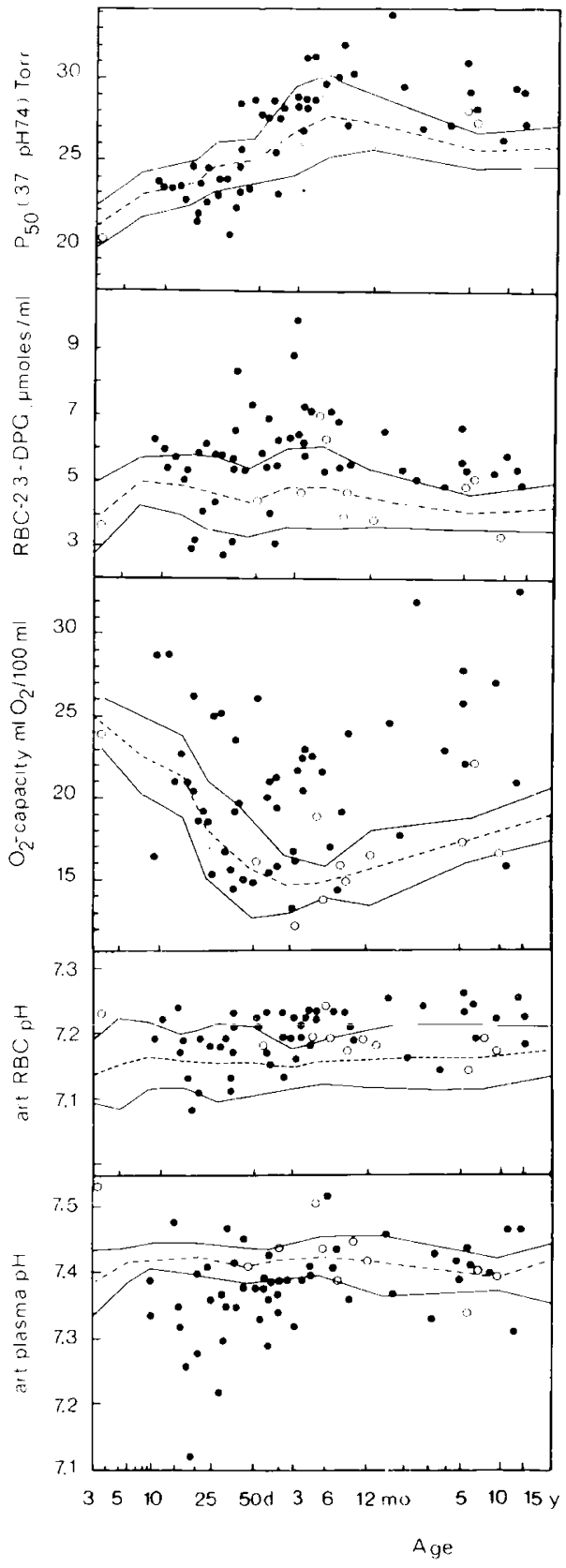

Fig. 1. Postnatal course of standard $\mathrm{P}_{50}$ value $\left(\mathrm{pH} 7.4 ; 37^{\circ}\right)$, red cell 2,3-diphosphoglycerate $(R B C-2,3-D P G)$ concentration, oxygen capacity, red cell $\mathrm{pH}$, and arterial plasma $\mathrm{pH}$ in infants suffering from cyanotic heart disease $(0)$ and acyanotic heart disease $(O)$ as compared with the mean $(\quad) \pm \mathrm{SD}(\longrightarrow)$ of normal individuals (data from Reference 29).

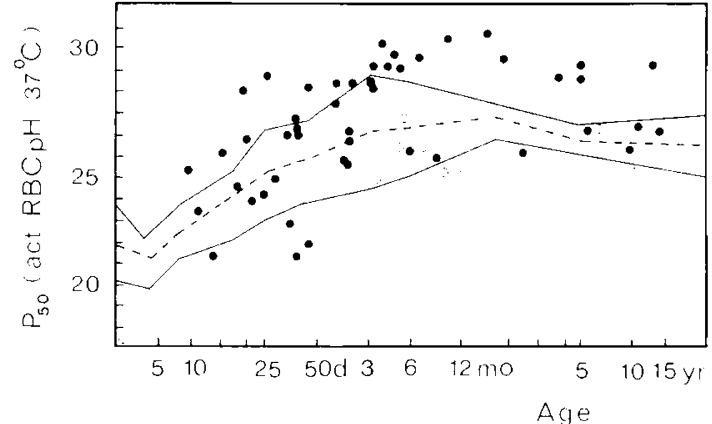

Fig. 2. Postnatal course of in vivo $\mathrm{P}_{50}$ at actual red cell $(a c t, R B C) \mathrm{pH}$, $37^{\circ}$. - , cyanotic heart disease: $O$, acyanotic heart disease as compared with the mean $(--) \pm \mathrm{SD}(-)$ of normal indivduals.

During the first 50 days of life the RBC 2.3-DPG levels were scattered around the normal range: after about the third month they were found to be generally elevated (Fig. 1). No arterial vs venous differences of RBC 2,3-DPG were found in samples collected from arterial and venous sites in the same individual during cardiac catheterization ( $n=15$; paired $t$-test).

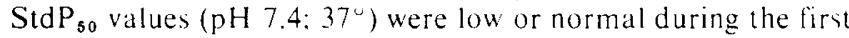
50 days, and elevated after the third month (Fig. 1). The act $P_{50}$ values were scattered around the normal range during the first 50 days and were moderately elevated later on (Fig. 2).

Blood $\mathrm{O}_{2}$ capacity was normal or elevated during the first 50 days of life. As in healthy individuals, there was a reduction in $\mathrm{O}_{2}$ capacity in the first trimester, although on a higher level. With increasing age the $\mathrm{O}_{2}$ capacity of cyanotic children exceeded that of normal individuals (Fig. 1). The substitution of $\mathrm{HbA}$ for $\mathrm{HbF}$ in the cyanotic infants was not different from that observed in healthy individuals. At comparable $\mathrm{HbA} / \mathrm{HbF}$ ratios the correlations of std $P_{50}$ vs RBC 2.3-DPG (Regression Equations 12 and 13 in Table 1) are in accordance with the literature $(10,29)$.

Arterial plasma $\mathrm{pH}$ was found to be decreased most frequently during the first 3 months of age, and to be normal later on. In contrast, the $\mathrm{RBC} \mathrm{pH}$ was not significantly reduced, and was elevated or normal after the third month (Fig. 1). The distribution ratio of hydrogen ions between plasma and red cells $\left(\mathrm{H}_{\mathrm{e}}^{+} / \mathrm{H}_{\mathrm{H}}^{+}\right)$in the hypoxemic infants is increased at any given plasma $\mathrm{pH}$ as compared with normoxemic control subjects (Fig. 3). independently of age. This means that at comparable plasma $\mathrm{pH}$ the $\mathrm{RBC}$ $\mathrm{pH}$ is elevated in hypoxemia. The data coincide with regressions found in vitro under similar conditions (5).

RBC 2,3-DPG increased with advancing hypoxemia in older children ( $\mathrm{HbF}<25 \%$; mean $9 \%$ ) if related to $\mathrm{paO}_{2}$ (Equation 5 , Table 1) or to $\mathrm{O}_{2}$ content of arterial blood $\left(\mathrm{CaO}_{2}\right)$ (Equation 3, Table 1$)$. In young infants ( $\mathrm{HbF}>35 \%$; mean $47 \%$ ) a significant correlation of RBC 2,3-DPG vs $\mathrm{paO}_{2}$ or $\mathrm{CaO}_{2}$ is found only if data of infants with a plasma $\mathrm{pH}<7.3$ are excluded (Equations 4 and 2 , Table 1). The correlations appear to be closer in older children; however, the slopes of the regressions are not significantly different among young and older infants, indicating that the 2,3-DPG response to hypoxemia is quantitatively the same in these two age groups at comparable plasma $\mathrm{pH}$.

The dependence of RBC 2.3-DPG on both the plasma $\mathrm{H}^{+}$ concentration $\left(\mathrm{H}_{\mathrm{e}}^{+}\right)$and on $\mathrm{O}_{2}$ saturation of hemoglobin is represented in Figure $4 a$ for older children (mean $\mathrm{HbF} 9 \%$ ) and in Figure $4 b$ for young infants (mean $\mathrm{HbF} 47 \%$ ). In both age groups there is a negative correlation between R BC 2,3-DPG and plasma $\mathrm{H}^{+}$; at a given plasma $\mathrm{H}^{+}$concentration the $\mathrm{RBC} 2,3-\mathrm{DPG}$ levels in hypoxemia exceed the values found in normoxemia by approximately $1.5 \mathrm{mM}$. Since high plasma $\mathrm{H}^{+}$concentrations (low plasma $\mathrm{pH}$ ) prevail in the young hypoxemic group, their average $\mathrm{RBC}$ 2,3-DPG does not exceed that of the young normoxemic group (Fig. $4 b$ ).

The relation between $\mathrm{RBC}$ 2,3-DPG and the actual intraerythrocytic $\mathrm{H}^{+}$concentration $\left(\mathrm{H}_{i}^{+}\right)$is represented in Figure $5 a$ for 
Table 1. Constants of regression equation: $y=b x+a^{1}$

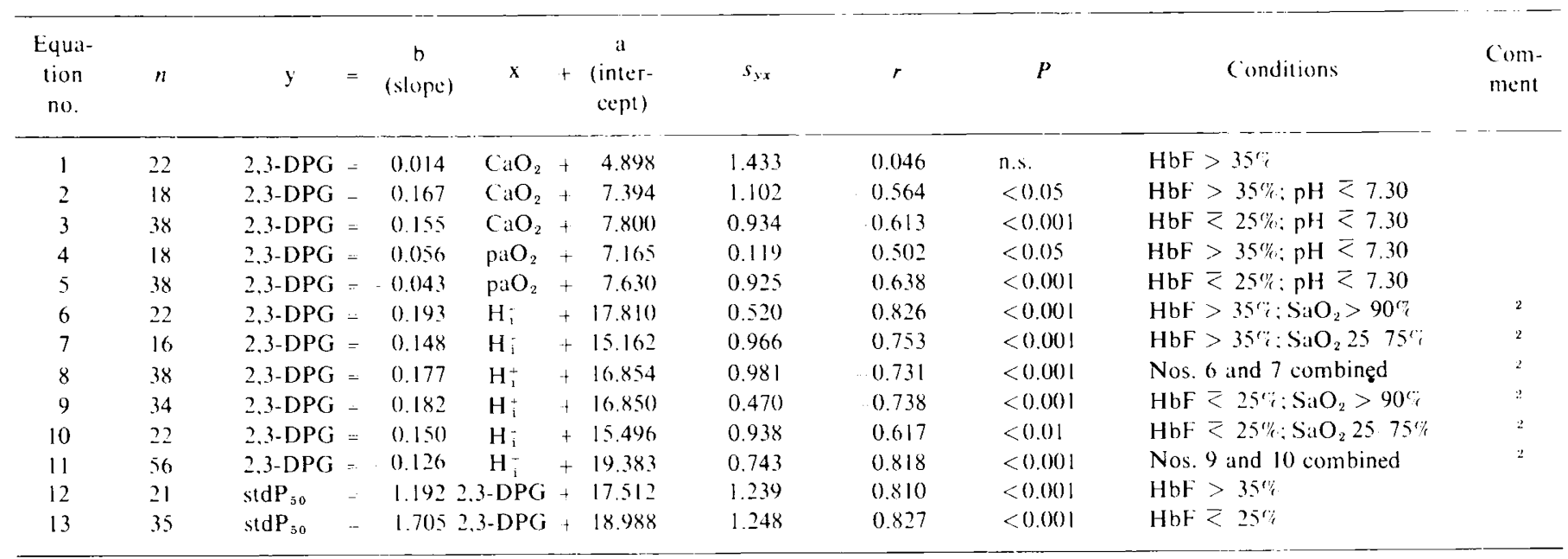

12,3-DPG: red cell 2,3-diphosphoglycerate (in millimolar concentration): $\mathrm{CaO}_{2}:$ arterial oxygen (in milliliters of $\mathrm{O}_{2}$ per $100 \mathrm{ml}^{\text {): }}$ paO $\mathrm{O}_{2}:$ arterial oxygen tension (Torr): $\mathbf{H}_{i}$ : intraerythrocytic hydrogen ion (in nanomolar concentration); std $\mathbf{P}_{50}: \mathbf{P}_{50}\left(\mathrm{pH} 7.4,37^{\circ}\right.$ ) (Torr): SaO $\mathrm{O}_{2}$; arterial oxygen saluration (percentage)

${ }^{2}$ Regression Equations 611 not significantly different with regard to slope (b) and intercept (a).

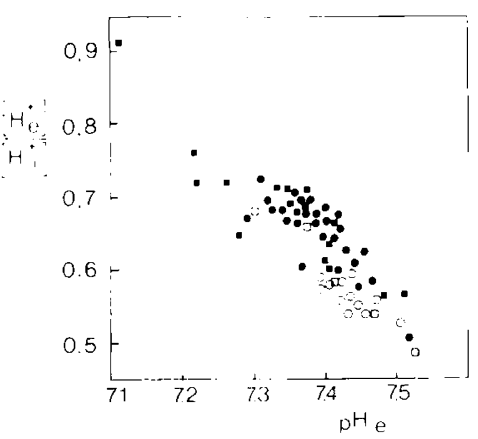

Fig. 3. Distribution ratio of extraterythrocytic over intraterythrocytic $\mathrm{H}^{+}$concentration $\left(\mathrm{H}_{e}^{+} / \mathrm{H}^{+}\right)$plotted is. arterial plasma $\mathrm{pH}\left(\mathrm{pH}_{e}\right)$, at different arterial oxygen saturations $\left(\mathrm{SaO}_{2}\right)$ in congenital heart disease. 口: $\mathrm{SaO}_{2}<80 \% ; \mathrm{O}, \square: \mathrm{SaO}_{2}<85 \%$. Relative red cell alkalinity in the hypoxemic subjects at any given plasma $\mathrm{pH}$ is evident. Values for young infants $(\square, \square$ : mean fetal hemoglobin $47 \%)$ and older children $(O$, mean adult hemoglobin $91 \%$ ) do not differ signilicantly.

older children, and in Figure sh for young infants. grouped according to normoxemia and hypoxemia. Both in the young infants and the older children R BC 2,3-DP(; correlates closely with $\mathrm{H}^{+}$(Equations 8 and 11 . Table 1). In these correlations the values of the hypoxemic and normoxemic groups coincide (Equaltions 6 and 7. Table 1, for young infants: Equations 9 and 10. Table 1 , for older children). There is no significant difference between these correlations of RBC 2,3-DPG is $\mathrm{H}_{\text {; }}^{+}$calculated for young infants and older children.

\section{DISCUSSION}

\section{IIO) RE(;LLATION (OF 2.3-IDPG IN CHRONIC HYPOXEMIA}

The 2,3-DPG increase in hypoxemia appears to be controlled by the oxygenation state of hemoglobin (2), although contradictory results have been described (23). In vitro two control mechanisms for $\mathrm{RBC} 2,3-\mathrm{DPG}$ by the $\mathrm{O}_{2}$ saturation of hemoglobin are established. Their relative importance in vivo is still under debate.

Mechanism 1.2,3-DPG is preferentially bound to adult deoxyhemoglobin $(6,9,14)$; a drop of free 2,3-DPG in deoxygenated erythrocytes has been discussed to enhance 2.3-DPG synthesis in hypoxemia via a relief of product inhibition of DPG mutase (6. 14. 21 ). Because of the low binding of $2,3-\mathrm{DPG}$ to $\mathrm{HbF}(11)$, a lower

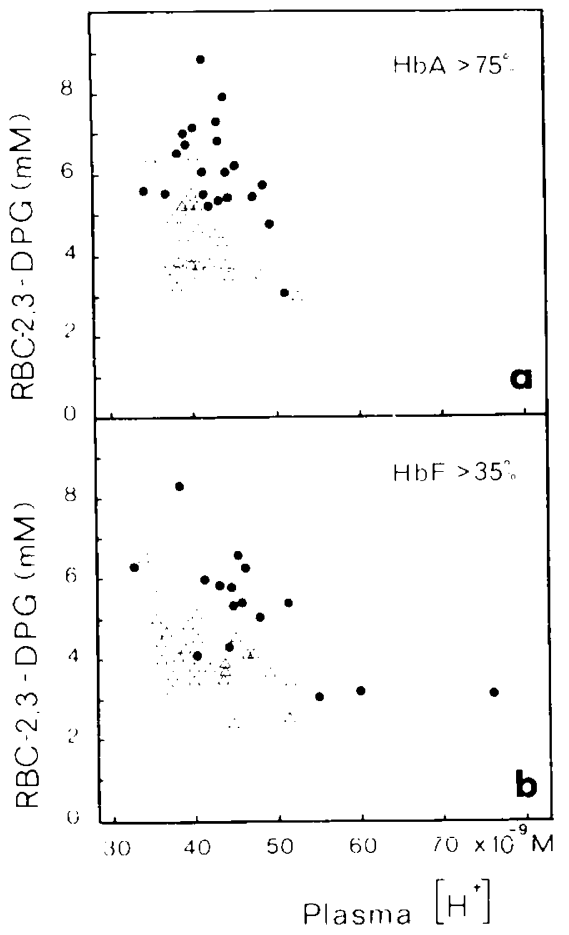

Fig. 4. Dependency of red cell 2,3-diphosphoglycerate ( $R B C-2,3-D P G)$ concentration on plasma $\mathrm{H}^{+}$concentration. $a$. older children (adult hemoglobin $(H h, 1)>75 \%$ : mean $\left.91^{\prime} \%\right): h$, young infants (fet:al hemoglobin $(H b F)>35 \%$, mean $47 \%)$. Normoxemic individuals $(\triangle) . \mathrm{SilO}_{2}>90^{\circ} \%$ (data from Reference 29): hypoxemic pattents $(0), \mathrm{SaO}_{2} 2575 \%$ "

response to hypoxemia should be expected in fetal erythrocytes. This has indeed been observed in vitro (21).

Mechanism 2. The $\mathrm{O}_{2}$ saturation of hemoglobin controls 2,3DPG synthesis and breakdown by influencing the intraterythrocytic $\mathrm{pH}$ (10). In vitro (1,5. 13) and also in vivo (Fig. 3) the intraerythrocytic pH increases when blood is deoxygenated, at any given plasma $\mathrm{pH}$, because of proton binding to deoxyhemoglobin (33) and a redistribution of diffusable charges, according to the Donnan equilibrium (26).

From the present data (Fig. 5), it appears that in vivo the RBC 2.3-DPG concentration is virtually regulated by the $\mathrm{RBC} \mathrm{pH}$. 


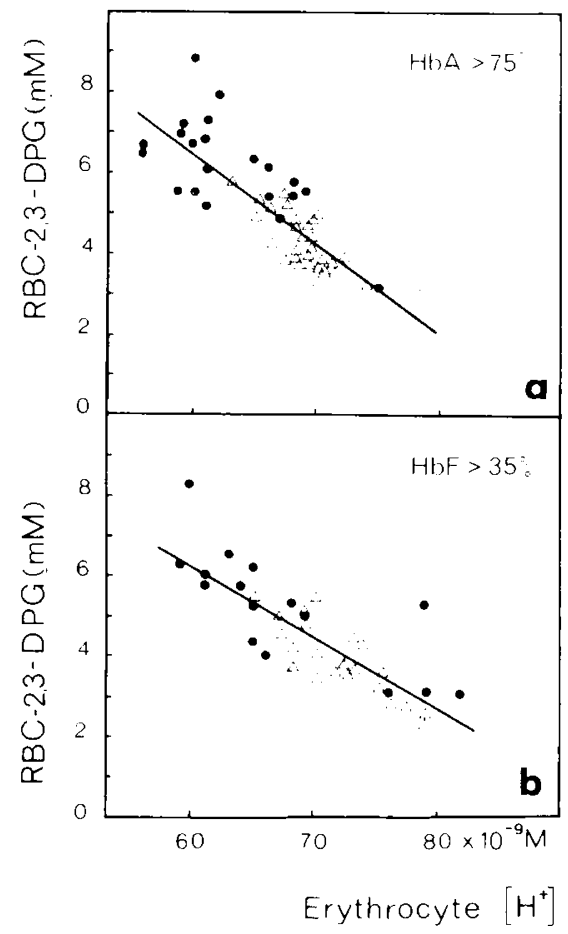

Fig. 5. Dependency of red cell 2,3-diphosphoglycerate $(R B C-2,3-D P G)$ concentration on intraerythrocytic $\mathrm{H}^{+}$concentration $\left(\mathrm{H}_{i}^{+}\right), a$, older children: $b$, young inliants. For conditions and symbols see Figure 4 . The correlation of 2,3-DPG $v s \mathrm{H}^{-}$is not significantly different in young infants and older children (see Regression Equations 8 and 11. Table 1). HbA, adult hemoglobin: $H b F$, fetal hemoglobin.

$\mathrm{RBC} \mathrm{pH}$, in turn, depends on the oxygenation state of hemoglobin and on plasma $\mathrm{pH}$

From the comparison of the presented correlations of $R B C$ 2,3-DPG is $\mathrm{H}^{+}$, which are not significantly different in hypoxemic young infants (Fig. 5b) and older children (Fig. 5a), it mas be concluded that in vivo the difference in 2,3-DPG binding to fetal or adult deoxyhemoglobin does not mealsurably influence the $R B C$ 2.3-DPG concentration.

In hypoxemia, RBC $\mathrm{pH}$ and, thus, 2,3-DPG were found to be elevated, provided plasma $\mathrm{pH}$ was normal. Low plasma $\mathrm{pH}$ was found to counteract the effect of hypoxemia on $\mathrm{RBC} \mathrm{pH}$ and 2,3-DPG, as in most of the young infants studied. Similar counteracting effects of low plasma $\mathrm{pH}$ and hypoxemia on $\mathrm{RBC}$ 2,3-DPG have been observed in the respiratory distress syndrome of the newborn $(10,12,22)$.

Additional factors, e.g., plasma inorganic phosphate, may contribute to the 2.3-DPG increase in hypoxemia. However, the correlation of 2.3-DPG is $\mathrm{H}^{+}$which we observed in hypoxemia is strictly the same as that found in patients with metabolic acid base disorders (3). This underlining the fact that $\mathrm{RBC} \mathrm{pH}$ is indeed the predominant regulator of 2,3-DPG metabolism.

Keitt and coworkers (17) excluded inorganic phosphate as a factor determining $\mathrm{RBC} 2,3-\mathrm{DPG}$ in patients with chronic obstructive lung disease. Furthermore, although these authors did not consider red cell $\mathrm{pH}$. a rough estimation of red cell $\mathrm{pH}$ from their data on the basis of our regression equations suggests that 2,3-DPG may correlate with red cell $\mathrm{pH}$ in their patients, both during sustained hypoxemia and after acute changes of the oxygenation state.

\section{PHYSIOLOGIC RELEVANCE OF OXYGEN AFFINITY IN SHUNT HYPOXEMIA}

A decrease in oxvgen affinity (high $P_{50}$ value) of blood enhances the release of oxygen from hemoglobin to the tissues (27) and thus compensates for a decreased cardiac output and/or reduced $\mathrm{O}_{2}$ content of blood (4). The generally accepted assumption. however. that a high $\mathrm{P}_{50}$ value implies an increased $\mathrm{O}_{2}$ unloading capacity of blood, is not applicable at low arterial oxygen tensions $(22,25,31)$, i.e., in the steep part of the oxygen equilibrium curve of hemoglobin. With increasing shunt hypoxemia the effect of $\mathrm{P}_{50}$ on $\mathrm{O}_{2}$ unloading diminishes $(22,25,30,31)$. In shunt hypoxemia the observed changes of the actual in vivo $\mathrm{P}_{50}$ (Fig. 2) should be of minor relevance, whereas adequate tissue oxygenation depends primarily on oxygen content of blood and thus mainly on red cell mass (28).

\section{SUMMARY}

In older children suffering from cyanotic heart disease an adaptive increase in $\mathrm{O}_{2}$ capacity, 2,3-DPG, and $\mathrm{P}_{50}$ occurs. I $n$ vivo the 2,3-DPG increase in hypoxemia appears to be controlled by the increased intraerythrocytic $\mathrm{pH}$ which, in turn. depends on the low $\mathrm{O}_{2}$ saturation of hemoglobin. In the first weeks of life 2,3-DPG is not elevated in infants with cyanotic heart disease because the low plasma $\mathrm{pH}$ frequently found in these babies is balancing the effect of hypoxemia on red cell $\mathrm{pH}$.

During hypoxemia, oxygen delivery to tissues depends on the $\mathrm{O}_{2}$ capacity rather than on the $\mathrm{O}_{2}$ affinity. Therefore, an insufficient increase of $\mathrm{RBC} 2.3-\mathrm{DPG}$ and of blood $\mathrm{P}_{50}$ in response to hypoxemia may not represent a serious disadvantage. Low hemoglobin concentration, however, must be considered a serious cause of hypoxia.

\section{REFERENCES AND NOTES}

1. Aresnnkat. W.: A further study of the metabolic buffer value and the Bohr effect in human fetal whole blood. Pediat. Res. 7: 996 (1973).

2. Asakura, T.. Sato. S. Minakami, S. and Yoshikawa, H.: Effect of deoxygenation of intracellular hemoglobin on red cell glycolysis. J. Biochem. (Tok yo). 5. $524(1966)$

3. Astrup, P.. Rörth, M., and Thorsauge, C.: Dependency on acid-base status of oxyhemoglobin dissociation and 2,3-diphosphoglycerate level in human erythrecytes. Scand. J. Clin. L ab. Invest., 26: 46 (1970)

4. Bauer. $C_{\text {: }}$ On the respiratory function of hemoglobin. Rev. Physiol. Biochem. Pharmacol., 70: I (1974)

5. Batuer. C.. and Schröder. F.: Carhamino compounds of haemoglobin in human adult and foetal blood. J. Physiol.. 227: 457 (1972)

6. Benesch. R. Benesch, R. E... and Yu. C. I.: Reciprocal hinding of oxrgen and 2.3-diphosphoglicerate bs human hemoglobin. Proc. Nat. Acad. Sci U. S. 1 59: $526(1968)$

7. Betke, K.. Marti, H. R.. and Schlicht. I.: Estimation of small percentages of foctal haemoglobin. Nature, 184: 1877 (1959)

8. Büicher. T.. Luh. W.. and Pelte. D.: Einfache und susammengesetzte optische Tests mit Pyridinnucleotiden. In: Hoppe-Seylers' Thierfelder: Handbuch der physiologie und pathol.-chem. Analyse, Ed. 10, Vol VI/A. p. 292 (Hoppe. New York. 1964).

9. Caldwell. P. R. B.. Nagel. R. L.. and Yaffé. E. R.: The effect of oxtgen. carbon dioxide. pH and cyanate on the hinding of 2.3-diphosphoglycerate to human hemoglobin. Biochem. Biophss. Res. Commun. 44: 1504 (1971)

10. Delivoria-Papadopoulos, M.. Roncevic, N. P.. and Oski, F. A. Postnatal changes in oxygen transport of term, premature and sick infants: The roke of red eell 2,3-diphosphoglycerate and adult hemoglobin. Pediat. Res.. 5: 235 (1971).

11. de Verdier. C. H. and (jarby, L.: Low binding of 2,3-diphosphoglycerate to hatemoglobin F: A contribution to the knowledge of the binding site and an explanation for the high oxygen affinity of foctial blood. Scand. I. Clin. Lab. Invest. 23: 149 (1969).

12. Duc, G., and Engel, K.: Hemoglobin-oxygen affinity and erythrocyte 2,3-diphosphoglycerate (DP(i) content in hyaline-membrane disease (HMD) and cardiac malformations (CM). Proceedings of the Second European Congress on Perinatal Medicine, London, 1970, p. 266 (Karger, Basel, 1971).

13. Duhm. J.. and Gerlach. F.: On the mechanism of the hypoxia-induced increase of 2,3-diphosphoglycerate in erythrocytes. Prlüger's Arch. Ges. Physiol., 326: 254 (1971).

14. (iarby, L., Gerber, (i., and de Verdier. C. H.: Binding of 2,3-diphosphoglycerate and adenosine triphosphate to human hemoglobin A. Eur. J. Biochem.. (1): $110(1969)$.

15. Geigy. A. G.. Jr. (Ed.): Documenta Geigy (Pharma. Basel, 1968).

16. Kaufmann, W.. Kömpf, J., and Dürr, F.: Wasserstoffionenkonzentration von Erythrocyten im Kalpillarblut bei Gesunden und Kranken mit Störungen des Säure-Basen-Gleichgewichts. Z. Ges. Exp. Med., 142: 57 (1967).

17. Keitt, A. S.. Hinkes, C., and Block, A. J.: Comparison of factors regulating red cell 2,3-diphosphoglycerate (2.3-DPG) in acute and chronic hypoxemia. J. Lab. Clin. Med., 84: 275 (1974).

18. Metcalfe. J.. Dhindsa, D. S.. Edwards. M. J.. and Mourdjinis. A.: Decreased 
aftinity of blood for oxygen in putients with low-output heart biture. (ire Res. 25: $47(1969)$

19. Morse. M.. Cassels. D. E.. and Holder. M.: The pusition of the oxygen dissociation curve of the hlood in cyanotic congenital heart discase. I. Clin Invest. 29: $1098(1950)$

20. Oski. F. A.. (iottlich. A. J., Delivoria-Papadopoulos. M.. and Miller. W. W Red-cell 2,3-diphosphoglscerate levels in subjects with chronic hypoxemia. $N$ Enol J Med 280: $1165(1969)$

21. Oski.F. A.. (iotelich. A. J.. Miller. W. W. and Delivoria-Papadopoules. M.: The effect of deongenation of adult and fetal hemoglobin on the symthesis of red cell 2,3-DP(; and its in wire consequences. J. Clin. Insest. fo: f(h) (1970)

22. Riegel. K. P.. and Versmold. H. Postnatial hlood oxyen transport. with special respect to idenathic respirators distress sondrome. Bull. Phosio-Pathol. Resp. 9: $1533(1973)$

23. Rose. Z. B.: Elfect of salts and pll on the rate of erythrocyte diphesphoglver rate mutase. Arch. Biochem. Biophis.. 158: 903 (1973)

24. Rosenthal. A., Mentzer, W. C., Fisenstein, E. B.. Nathan, D. (i.. Nelson, N. M. and Nadas. A. S.: The role of red eell organic phosphales in adaptation to congenital heart disease. Pediatrics, 47:537(1971).

35. Turek. Z.. Kreuzer, F.. and Hoofd, L. J. C. Advantage or disadvantages of a decrease of blood oxygen affinity for tissuc onygen supply at hypoxia. Pflieger' Arch. Ges. Physiol.. 342: 185(1973)

26. van Slyke. D. D.. Hastings, A. B.. Murrat. C. D... and Sendror. J.: Studies of gas and electrolyce equilibria of hloud. VIIl. The distribution of hadrogen. chtoricle and biearbenate ions in oxygenated and reduced blood. 1. Biol. (hem.. 65: 701 (1925).

27. Versmold, H., and Brauser. B.: Improsed cellular oxygenation by 2,3-diphosphoglvcerate: Quantitative measurement of tissue hypoxia he registration of absorption spectra of cytochrome $a$ and hemoglobin in the intact organ. In: $t$. Gerlach, K. Moser. and W. Wilmanns. Ervthrocstes. Thrombecstes. Leuco- cytes, p. 170 (Thicme, Stutgart. 1973)

28. Versmeld, $H$.. Linderkamp. O. Bühlmever. $K$.. and Riegel, $K$.: Dals Blutvolu men. die Hämoglobinmasse und die arteriellen () $)_{2}$-Parameter bei angeborenen Herzfehkern von Säuglingen und Kindern. Mschr. Kinderbeilk., /19: 414 (1971).

29. Versmold. H. Seifert, ( $;$., and Riegel, $K$. P.: Blood oxygen affinits in infance The interation of fetal and adult hemoglobm, oxven capacity, and red cell hydrugen ion and 2 3-diphosphuglsceralle concentration. Resp. Phosiol.. 18: 14 (197.3).

30. Versmold, H.. Wenner. J., and Riegel, K. P.: Changes of blood oxygen affinity and capacity and red cell 2,3-diphosphoglycerate evoled by exchange transfusion with $\mathrm{ACD}$-preserved blood in newborn infints: Their interceliltionship and influences on oxegen supply of tissues and erythropoiesis. Z. Kinderbeilk.. //3. I (1972).

31. Woodson. R. D.: Red cell adaptation 10 cardiorespiratory disciace. (lin Hematol.. 3: 627 (1974).

32. Woudson. R. D., Torrance. J. D.. Shapell. S. D).. and Lentiant. ( . The effect of

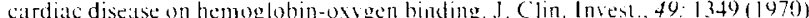

33. Wyman. J.: Heme nroteins. Advan. Protein (hem.. 4: 407 (1948).

34. We wish to thank Dr. J. Duhm for critical revision of the manuscript. Ms. Heid Windthorst for perfect technical assistance, E. Rohrhuber for statistical evaluations, and Ms. Susan E. Shealy for atid in preparing the manuscript.

35. This work was supported by Deutsche forschungsgemeinschaft (SFB S1. Klinische Molekularbiologic und Biochemic)

36. Parts of this materiall were presented at the Neeting of the European Pediatric Respiration Cluh. Pont-i-Mousson. September 1973.

37. Requests for reprints should be addressed to: H. Versmold. M.D. Liniversitäts kinderklinik, D-8 München 2, Lindwurmstr. 4. Federal Republic of (iermans.

38. Accepted for publication December 3. 1975.
Antibiotics

heart

inotropic agent newborn

sympathetic nervous system

\title{
Response of the Neonatal Heart to a New Inotropic Agent, RO2-2985 (X537A)
}

\author{
PAUL C. GILLETTE, ${ }^{22}$ RONAID G. MUNSON. ROBERT M. LEWIS, AND ARNOLD SCHWARTZ \\ Department of Cell Biophswies. Division of Mrocardial Biologi, and Department of Pediatrics. Section of \\ Cardiology. Baylor College of Medicine and the Fondren-Brown Cardiovascular Research and Training C'enter. The \\ Methodist Hospital. Houston. Texas. L:S.4
}

\section{Extract}

The ionophore RO2-2985 did not produce a positive inotropic response in 1-day-old canine isolated ventricle. A gradual increase in inotropic response was seen with age. Isolated atria, however, exhibited a positive inotropic response at birth $(50 \%$ increased $\mathrm{dF} / \mathrm{dt}$ ), which became progressively greater with age $(100 \%$ increase in $\mathrm{dF} / \mathrm{dt}$ at $\mathbf{1 5}$ days of age $/$. In the neonatal heart in situ there was a positive inotropic response in 1-day-old puppies $140 \%$ increase in left ventricular $\mathrm{dF} / \mathrm{dt}$ ) with progressively greater responses with age $(135 \%$ increase in left ventricular $\mathrm{dF} / \mathrm{dt}$ at 11 days of age). There was a positive chronotropic $(75-125 \%$ increase) response to RO2-2985 at all ages studied. The drug elevated systemic arterial pressure ( $150 \%$ increase in mean arterial pressure) to a similar degree in all ages studied. RO2-2985 depressed total calcium binding by both neonatal and adult isolated cardiac sarcoplasmic reticulum approximately $50 \%$.

\section{Speculation}

Although the exact mechanism of action of RO2-2985 on the heart remains unproven, the temporal association of the increase in ventricular and atrial sympathetic nerve endings with development reported by previous authors and the increase in response to RO2-2985 and tyramine suggest that the drug might act in part by releasing a humoral substance. The discrepancy between in situ and isolated studies tends to support this view. A more complete delineation of all subcellular fractions of the developing heart will be necessary to clarify the differential actions of this and other drugs on the developing heart. RO2-2985 may be of value in the treatment of low cardiac output states in neonates as well as adults, but specific testing in neonates will be necessary.

The antibiotic ionophore RO2.-2985 (Hofmann-LaRoche), in exerting a significant effect on the cardiovascular system. 